\title{
The Struggle of Hybrid Entepreneur in The New Normal Era
}

\author{
Ni Putu Sintha Devi Yogandhi ${ }^{(1)}$ \\ Gede Sri Darma ${ }^{(2)}$ \\ Universitas Pendidikan Nasional (1)(2) \\ ysinthadevi@gmail.com ${ }^{(1)}$ \\ sridarma@undiknas.ac.id ${ }^{(2)}$
}

\begin{abstract}
This study aims to know and analyze about Hybrid Entrepreneur and the strategy of Hybrid Entrepreneur in the New Normal Era. The research setting is the physical environment with a qualitative approach. Key Informan is a Hybrid Entrepreneur determined by Purposive Sampling technique. Data collection was done by interviews, observations and documentation. The data source is from sources that can be used as a Hybrid Entrepreneur model and process by using Strategy Management approach with technical analysis of strategy formulation is based on a three-stage framework of strategy formulation with analysis tools Internal Factor Evaluation Matrix, External Factor Evaluation Matrix, Strengths-Weakness-OpportunitiesThreats Matrix and the Quantitative Strategic Planning Matrix. The conclusion are to become a Hybrid Entrepreneur should be based on expertise, while also having the ability to take opportunities and the courage in making business decisions. Market Penetration Strategy is the most appropriate strategy in facing competition in this New Normal era with the best long-term strategy is Integration Strategy, which is to increase the sales network directly to consumers, then increase control over suppliers for product innovation development, and increase competitiveness among others by acquiring competitors.
\end{abstract}

\section{Keywords : Hybrid Entrepreneur; New Normal; SWOT; Strategy; Business}

\begin{abstract}
ABSTRAK
Penelitian ini bertujuan untuk mengetahui dan menganalisis tentang Hybrid Entrepreneur dan strategi Hybrid Entrepreneur di Era New Normal. Setting penelitian adalah lingkungan fisik (physical site) dengan pendekatan kualitatif. Narasumber merupakan Hybrid Entrepreneur ditentukan dengan teknik Purposive Sampling. Pengumpulan data dilakukan dengan cara wawancara, observasi dan dokumentasi. Data penelitian bersumber dari model Hybrid Entrepreneur dengan pengolahan data menggunakan pendekatan Manajemen Strategi dengan teknis analisis formulasi strategi didasarkan pada kerangka kerja tiga tahap formulasi strategi dengan alat bantu analisis Matriks Internal Factor Evaluation, Matriks External Factor Evaluation, Matriks Strengths-Weakness-Opportunities-Threats dan Matriks Quantitative Strategic Planning Matrix. Kesimpulan penelitian mendapatkan untuk menjadi seorang Hybrid Entrepreneur harus dilandasi dengan keahlian dalam bidang yang hendak dijalani, sekaligus juga memiliki kemampuan untuk menangkap peluang dan keberanian dalam mengambil keputusan bisnis. Strategi Penetrasi Pasar merupakan strategi yang paling tepat dalam menghadapi persaingan di era New Normal ini dengan Strategi jangka panjang yang terbaik adalah Strategi Integrasi, yaitu dengan meningkatkan jejaring penjualan langsung kepada konsumen, kemudian meningkatkan kendali atas pemasok untuk pengembangan inovasi produk, dan meningkatkan daya saing diantaranya dengan pengambilalihan atau mengakuisisi pesaing.
\end{abstract}

Kata kunci : Hybrid Entrepreneur; New Normal; IFE; EFE; SWOT; QSP 


\section{INTRODUCTION}

Changes in social and economic conditions in the New Normal era forced most of the workforce to adjust (Sparrow, et.al., 2020; Darma and Noviana, 2020; Priskila and Darma, 2020; Shavitri and Darma, 2020; Sudiwedani and Darma, 2020; Handayani and Darma, 2021; Yong and Darma, 2020). Changes in the way of thinking are the main key to a person's success in maintaining self-existence. In addition, seeing the change itself as a new challenge to have various golden opportunities (Ledriyono, 2021; Swari and Darma, 2019; Wahyuni and Darma, 2019; Maharani and Darma, 2018; Kusuma and Darma, 2020; Ferdiana dan Darma, 2019; Permanasari dan Darma, 2013; Darma, 2012; Darma, 2004; Arsriani and Darma, 2013; Dewi and Darma, 2018). According to Buheji (2020), it is said that the New Normal is a broad consequence of changes in the modern world (such as climate change, migration, war, poverty, hunger), apart from the effects of technological developments. New Normal is the result of all changes in behavior and habits carried out during the Covid-19 pandemic which has changed people's lifestyles (Wardana et. al., 2021; Wardana and Darma, 2020; Wulandari and Darma, 2020; Murti and Darma, 2021). New Normal is an adjustment to the order of social behavior that has never existed before as an effort to stay productive and avoid the transmission of Covid-19 during the pandemic (Wijaya, 2021; Karniawati and Darma, 2021; Agung and Darma, 2019).

Hybrid Entrepreneurship is defined as an individual who engages in entrepreneurial activity and at the same time has a primary job that has a wage (Folta et.al., 2010; Krismajayanti and Darma, 2020). The fact that Indonesia's economic condition is in the shadow of a recession due to the uncertainty of economic growth due to the COVID-19 pandemic still has the potential to reduce and reduce employment opportunities for the majority of the workforce in Indonesia (Saturwa, et.al., 2021; Darma et al., 2019; Rivaldo et al., 2021; Darmayanti and Darma, 2020; Wulandari and Darma, 2020). This condition makes Hybrid Entrepreneurs can be used as an alternative solution in overcoming these potential problems. Based on this definition, Hybrid entrepreneur can be interpreted as a new way to get additional income or economic improvement that someone wants is a process where an entrepreneur builds his business gradually while still having a paid job (Marshall, et.al., 2020). That way individuals can test the entrepreneurial stage and gain knowledge and experience during starting to learn about business potential and individuals who have entrepreneurial characteristics and skills (Pollack, et.al., 2019; Umami and Darma, 2021; Dewi and Darma, 2019; Kusnadi and Darma, 2018; Handika and Darma, 2018; Wandari and Darma, 2021; Darma, 2005; Darma, 2005; Hendhana and Darma, 2017; Saefulloh and 
Darma, 2014; Darma, 2005).

The implementation of large-scale social restrictions with various controls on community social and economic activities which is a solution in preventing the expansion of the spread of COVID-19 in Indonesia must be accompanied by solutions for workers who are potentially affected by this policy (Poliyando and Kartiwi, 2021). Given the impact of the COVID-19 Pandemic, this research will focus on the strategy of becoming a Hybrid Entrepreneur in the New Normal era. The focus of this research is considered as an alternative to workers and a means to earn additional income or income in meeting the needs of life and improving the economy. Entepreneurship will be the best way to solve the poverty and unemployment problem (Dalimunthe, et.al., 2021).

This study aims to know and analyze about Hybrid Entrepreneurs where little is known about how to enter Hybrid entrepreneurs in starting their business (Xi et.al, 2017). The findings of Reema Bhagat (2019) in his research state that people with higher innovation have a higher tendency to take risks and therefore in general they choose the path of Entrepreneurship. This research also wants to know and analyze the best strategy for Hybrid Entrepreneurs in the New Normal Era, which according to the results of research by Ferreira et.al. (2019) stated that one of the strategies for successful Hybrid Entrepreneurs is to build a brand which implicitly provides some examples of best practices for building a loyal customer base as well as marketing problems that will be encountered when an entrepreneur grows their business.

\section{RESEARCH METHODOLOGY}

The research setting is the physical environment with a qualitative approach. This research was conducted at Istana Timber, which is owned by a resource person who is a Hybrid Entrepreneur and located at Gatot Subroto Barat Streer, Number 333, Pemecutan Kaja, North of Denpasar District, Denpasar City, Bali, which is the main location where research sources run their business and is a place where the process of making strategic decisions related to the running of the company's business is carried out. The time of the study was carried out from June to July 2020.

The data of this research is sourced from Mr. I Made Soka Guinastra as a interviewess in research that can be used as a Hybrid Entrepreneur model which is considered to be able to seize opportunities and implement business strategies that can survive in the New Normal era. What is determined by the purposive sampling technique is based on the purpose because the person concerned has data or information related to the research being carried out. Data 
was collected by means of interviews, observation, and documentation.

Data processing method uses a Strategic Management approach with technical analysis of strategy formulation based on a three-stage strategy formulation framework consisting of an input stage. Matching stage (matching stage) and decision stage (decision stage), with analysis tools Internal Factor Evaluation (IFE) Matrix, External Factor Evaluation (EFE) Matrix, Strengths-Weakness-Opportunities-Threats (SWOT) Matrix, and Quantitative Strategic Planning Matrix Matrix (QSPM).

\section{RESULTS AND DISCUSSION}

The owner of Istana Timber opened a furniture business while still working as an employee in a company. The opening of the Furniture business was motivated by the expertise that was previously passed down from generation to generation from the family. According to Darma (2018), an entrepreneur must have knowledge and skills in the field of management and know in detail the business he will be involved in and what is no less important is to have high creativity and innovation. Furthermore, Hendro and Chandra (2006) explained that entrepreneurship is the ability to manage something that exists within to be utilized and improved so that it is more optimal, including the ability to see opportunities and make critical decisions to improve the standard of living.

This result is supported by the research of Widya Hadi (2015) who in his research on the factors related to the formation of Entrepreneurial Intentions, especially young people to become entrepreneurs, found that one of the factors that have a significant positive influence is the relationship between individual skill attitude towards entrepreneurial behavior. Then, research from Mahmud \& Ariati (2011), one of the results stated that entrepreneurial orientation has a positive and significant influence on business strategy, management ability has a positive and significant influence on business performance. Sufficient management ability will determine the success of business performance (Tay, 2019).

The owner of Istana Timber to started a furniture business is based on confidence in his ability to make furniture products and his ability to see opportunities and the courage to make decisions to do business. This is referred to as a Hybrid Entrepreneur, as stated by Folta et.al. (2010), who define a Hybrid Entrepreneur as an individual who engages in entrepreneurial activity and at the same time has a primary job that has a wage". Thus, it can be concluded that in deciding to become a Hybrid Entrepreneur, it must be based on expertise in the field to be pursued, as well as having the ability to seize opportunities and courage in making business decisions. 


\section{Step I : Strategy Planning}

Internal Environmental Analysis

IFE matrix of Istana Timber produces a weighted score calculation for its internal factors. The results of the calculation of the IFE Matrix get a weighted score with the highest score being on the Quality factor, which is 0.44 , while the lowest weighted score is on the Website Access, Marketing Techniques, and Promotions factor with a weighted score of 0.08 each. The total weighted score for all Internal Factors at Istana Timber gets a score of 2.58. Based on the results of this weighted score calculation, it can be said that Istana Timber has a strong internal position. Based on the results of the weighted score matrix of the key internal factors, it can be concluded that quality along with brand, service, quality, product durability, production capability, and business location, is a key internal strength factor in the Istana Timber's business. While the factors of web access, product durability, and promotion are the key weakness factors of Istana Timber.

External Environmental Analysis

EFE Matrix of Instana Timber produces a weighted score calculation for its external factors. The results of the calculation of the EFE Matrix get a weighted score with the highest value being on the Consumer Taste, Quality, and Consumer Loyalty factors, each of which is 0.48, while the lowest weighted score is on the Counterfeit Product factor with a weighted score of 0.03. The total weighted score for all External Factors at Istana Timber is 2.76. Based on the results of this weighted score calculation, it can be said that Istana Timber has a moderate response to its business opportunities and threats. It can be concluded that the production cost factor, which is followed by the competitor factor and economic condition factor and then the raw material factor and imitation product, becomes a threat to the key external factors in Istana Timber's business.

\section{Step II : Strategy Matching}

The results of the calculation of the weighted score of Internal Factor Evaluation (IFE) show a total score of 2.58, then the results of the calculation of the weighted score of External Factor Evaluation in Table 4.2 show a total weighted score of 2.76. 


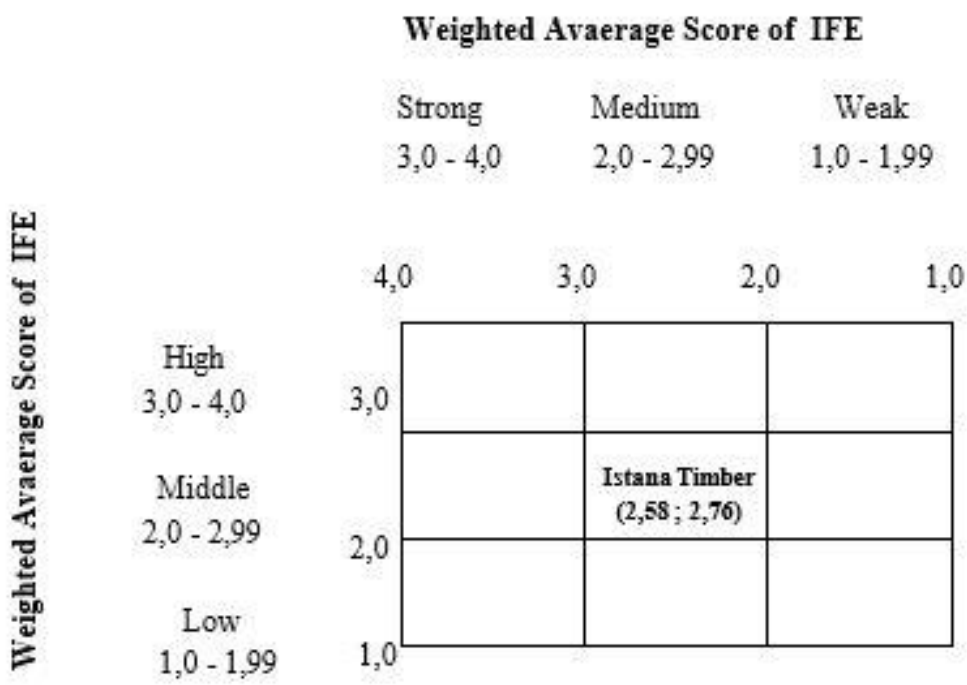

Figure 1. Internal and External Matrix Factors of Instana Timber

Source: Primary Data Analysis by Researchers (2020)

Figure 1 shows the coordinate position of the calculation results of Internal and external factors at the Istana Timber which is described in the form of an Internal External Matrix in

Cell V (fifth), with the category of medium strength, both internally and externally. SWOT Analysis

The SWOT analysis of the Istana Timber is used to evaluate the strengths, weaknesses, opportunities, and threats in its business, involves determining the specific objectives of Istana Timber and identifying its internal and external factors.

Table 1. Weighted Score of Internal Factor Evaluation of Istana Timber

\begin{tabular}{|l|l|l|l|l|}
\hline Code & \multicolumn{1}{|c|}{$\begin{array}{c}\text { Key of Internal } \\
\text { Factors }\end{array}$} & Score & Ranking & \multicolumn{1}{|c|}{$\begin{array}{c}\text { Weighted } \\
\text { Score }\end{array}$} \\
\hline \multicolumn{2}{|c|}{ Strengths (S) } & & & \\
\hline S1 & Brand & 0.08 & 4 & 0.33 \\
\hline S2 & Service & 0.11 & 3 & 0.33 \\
\hline S3 & Quality & 0.11 & 4 & 0.44 \\
\hline S4 & Product Durability & 0.08 & 3 & 0.25 \\
\hline S5 & Production Capability & 0.08 & 4 & 0.33 \\
\hline S6 & Business Location & 0.08 & 3 & 0.25 \\
\hline & & & Total $\left(\sum S\right)$ & 1.94 \\
\hline & Weaknesses(W) & & & 0.22 \\
\hline W1 & Human Resources & 0.11 & 2 & 0.17 \\
\hline W2 & Business Scale & 0.08 & 2 & 0.08 \\
\hline W3 & Website Access & 0.08 & 1 & \\
\hline
\end{tabular}




\begin{tabular}{|c|c|c|c|c|}
\hline W4 & Marketing & 0.08 & 1 & 0.08 \\
\hline W5 & Promotion & 0.08 & 1 & 0.08 \\
\hline \multicolumn{4}{|r|}{ Total $\left(\sum \mathrm{W}\right)$} & 0.64 \\
\hline & Total & 1.00 & & 2.58 \\
\hline \multicolumn{4}{|r|}{ S-W } & 1.31 \\
\hline
\end{tabular}

Source: Primary Data Analysis by Researchers (2020)

Table 1 shows the strength factor weighted score - the weakness factor weighted score is $2.22-0.64=1.31$, and will be used as the coordinates of point $\mathrm{X}$ in the IE diagram.

Table 2. Weighted Score of External Factor Evaluation of Istana Timber

\begin{tabular}{|c|c|c|c|c|}
\hline Code & Key of External Factors & Score & Ranking & $\begin{array}{c}\text { Weighted } \\
\text { Score }\end{array}$ \\
\hline \multicolumn{5}{|c|}{ Opportunities (O) } \\
\hline $\mathrm{O} 1$ & Consumer Preferences & 0.12 & 4 & 0.48 \\
\hline $\mathrm{O} 2$ & Advanced of Technology & 0.06 & 3 & 0.18 \\
\hline $\mathrm{O} 3$ & Purchasing Power & 0.12 & 4 & 0.48 \\
\hline $\mathrm{O} 4$ & Loyalty & 0.12 & 4 & 0.48 \\
\hline $\mathrm{O} 5$ & Market Prospects & 0.12 & 3 & 0.36 \\
\hline \multicolumn{5}{|c|}{\begin{tabular}{l|l|} 
Total $\left(\sum \mathrm{O}\right)$ & 2.00 \\
\end{tabular}} \\
\hline \multicolumn{5}{|c|}{ Threats (T) } \\
\hline $\mathrm{T} 1$ & Production Cost & 0.12 & 2 & 0.24 \\
\hline $\mathrm{T} 2$ & Competitors & 0.09 & 2 & 0.18 \\
\hline $\mathrm{T} 3$ & Imitation Products & 0.03 & 1 & 0.03 \\
\hline $\mathrm{T} 4$ & Raw Materials & 0.12 & 1 & 0.12 \\
\hline T5 & Economic Condition & 0.09 & 2 & 0.18 \\
\hline \multicolumn{4}{|r|}{ Total $\left(\sum \mathrm{T}\right)$} & 0.76 \\
\hline & Total & 1.00 & & 2.76 \\
\hline \multicolumn{4}{|r|}{$\mathbf{O}-\mathbf{T}$} & 1.24 \\
\hline
\end{tabular}

Source: Primary Data Analysis by Researchers (2020)

Table 2 shows the results of the calculation of the weighted score for the evaluation of the external factors of Istana Timber with the total weighted score for the opportunity factors $(\mathrm{O})$ amounting to 2.00 and the total weighted score for the threat factors being 0.76 . Thus, the opportunity factor weighted score $(\mathrm{O})$ - the threat factor weighted score $(\mathrm{T})$ is $2.00-0.76=$ 1.24 , and henceforth will be used as the coordinates of point $\mathrm{Y}$ in the grand strategy diagram. The following presents the results of the calculation of the weighted score of the Internal and External factors of Istana Timber in the form of a SWOT Matrix : 
Table 3. SWOT Analysis Matrix

\begin{tabular}{|c|c|c|}
\hline & STRENGHTS (S) & WEAKNESSES (W) \\
\hline $\begin{array}{l}\text { EXTERNAL } \\
\text { FACTORS }\end{array}$ & $\begin{array}{r}\text { 1. Brand } \\
\text { 2. Service } \\
\text { 3. Quality } \\
\text { 4. Product Durability } \\
\text { 5. Production Capability } \\
\text { 6. Business Location }\end{array}$ & $\begin{array}{r}\text { 1. Human Resources } \\
\text { 2. Business Scale } \\
\text { 3. Website Access } \\
\text { 4. Marketing }\end{array}$ \\
\hline OPPORTUNITIES (O) & SO - STRATEGIES & WO - STRATEGIES \\
\hline $\begin{array}{r}\text { 1. Consumer Preferences } \\
\text { 2. Advanced of Technology } \\
\text { 3. Purchasing Power } \\
\text { 4. Loyality } \\
\text { 5. Market Prospects }\end{array}$ & $\begin{array}{l}\text { 1. Strengthening Brand Image while still } \\
\text { paying attention to Consumer Taste by } \\
\text { considering consumer's purchasing } \\
\text { power } \\
\text { 2. Improved service and product quality to } \\
\text { foster consumer loyalty } \\
\text { 3. Increase product durability by } \\
\text { utilizing advances in wood } \\
\text { technology to increase market share. }\end{array}$ & $\begin{array}{l}\text { 1. Improving the quality of human resources by } \\
\text { increasing the ability of employees by the } \\
\text { competencies needed to be able to make } \\
\text { products that suit consumer tastes and can } \\
\text { meet market needs } \\
2 . \quad \text { Expanding business reach by utilizing } \\
\text { internet technology to expand product } \\
\text { marketing } \\
\text { Improve Marketing Techniques and use the } \\
\text { latest technology to expand marketing reach. } \\
\text { Promoting price package innovations while } \\
\text { still paying attention to purchasing power } \\
\text { and expanding marketing reach in every } \\
\text { location that has high market prospects }\end{array}$ \\
\hline THREATS (T) & ST - STRATEGIES & WT - STRATEGIES \\
\hline $\begin{array}{r}\text { 1. Production Cost } \\
\text { 2. Competitors } \\
\text { 3. Imitation Product } \\
\text { 4. Raw Materials } \\
\text { 5. Economic Condition }\end{array}$ & $\begin{array}{l}\text { 1. Making creations by using local raw } \\
\text { materials to reduce production costs and } \\
\text { updating models regularly as an effort to } \\
\text { suppress counterfeit products. } \\
\text { 2. Reducing production costs by taking into } \\
\text { account the decline in economic } \\
\text { conditions while still paying attention to } \\
\text { quality aspects } \\
\text { Improved service and product quality } \\
\text { in anticipation of business } \\
\text { competitors }\end{array}$ & $\begin{array}{l}\text { 1. Making products in the form of } \\
\text { Packages/Sets as an effort to reduce } \\
\text { distribution and raw material costs } \\
\text { 2. Improving the quality of a website that is } \\
\text { more attractive and informative as an effort } \\
\text { to expand the reach of business at a low } \\
\text { cost. } \\
\text { Increase promotion to anticipate the } \\
\text { invasion of counterfeit products and } \\
\text { Competitors. } \\
\text { Opening of new service and sales } \\
\text { locations with due regard to } \\
\text { economic conditions }\end{array}$ \\
\hline
\end{tabular}

Source: Primary Data Analysis by Researchers (2020)

The Grand Strategy Matrix is based on the results of the calculation of the weighted score of internal and external factors of Istana Timber shown by a diagram below 


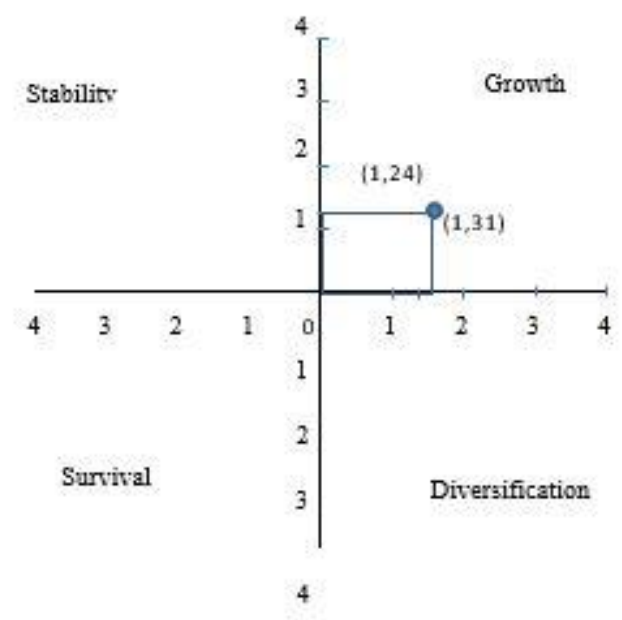

Figure 2. Grand Strategies Diagram

Source: Primary Data Analysis by Researchers (2020)

Figure 2 shows the Grand Strategy diagram based on the weighted score of Istana Timber internal and external factors. The point of intersection of the $\mathrm{X}$-axis $(\mathrm{S}-\mathrm{W})$ and the Y-axis (O-T) is in Quadrant I of the Grand Strategy diagram. Companies that are in quadrant 1 of the grand strategy diagram are in the Growth category. The best strategies for the position of Istana Timber in Quadrant I are 1) Market development, 2) Market penetration, 3) Product development, 4) Forward integration, 5) Backward integration, and 6) Horizontal integration.

Furthermore, David (2012) said that companies that are in quadrant 1 of the grand strategy matrix are in a very good strategic position. For all of these companies, constant concentration on current markets (market penetration and market development) and products (product development) is the right strategy. Based on the results of the Grand Strategy Matrix above, it can be concluded that Istana Timber is in Quadrant I of the Grand Strategy Matrix. Thus, the right strategies to use are market development and market penetration strategy.

\section{Step III : Strategic Decision Making}

The QSPM matrix is the result of calculating the attractiveness total score of the Internal and external factors of Istana Timber on the Market Penetration strategy. The highest score was achieved for the market penetration strategy, which was 7.10 and the lowest was the Market Development strategy, which was 6.64. Based on the results of the calculation of the QSPM Matrix, the market penetration strategy is the best strategy that must be taken by Istana Timber in running its business. 
Table 4. Quantitative Strategic Planning Matrix (QSPM)

\begin{tabular}{|c|c|c|c|c|c|}
\hline \multirow{2}{*}{ FACTORS } & \multirow{2}{*}{ SCORE } & \multicolumn{2}{|c|}{ Market Deveopment } & \multicolumn{2}{|c|}{ Market Penetration } \\
\hline & & AS & TAS & AS & TAS \\
\hline \multicolumn{6}{|l|}{ STRENGHTS } \\
\hline Brand & 0.08 & 4 & 0.33 & 4 & 0.33 \\
\hline Service & 0.11 & 4 & 0.44 & 3 & 0.33 \\
\hline Quality & 0.11 & 4 & 0.44 & 4 & 0.44 \\
\hline Product Durability & 0.08 & 3 & 0.25 & 4 & 0.33 \\
\hline Production Capability & 0.08 & 2 & 0.17 & 3 & 0.25 \\
\hline Business Location & 0.08 & 3 & 0.25 & 4 & 0.33 \\
\hline \multicolumn{6}{|l|}{ WEAKNESSES } \\
\hline Human Resources & 0.11 & 3 & 0.33 & 3 & 0.33 \\
\hline Business Scale & 0.08 & 3 & 0.25 & 4 & 0.33 \\
\hline Website Access & 0.08 & 4 & 0.33 & 3 & 0.25 \\
\hline Marketing & 0.08 & 2 & 0.17 & 3 & 0.25 \\
\hline \multirow[t]{2}{*}{ Promotion } & 0.08 & 4 & 0.33 & 4 & 0.33 \\
\hline & 1.00 & & 3.31 & & 3.53 \\
\hline \multicolumn{6}{|l|}{ OPPORTUNITIES } \\
\hline Consumer Preferences & 0.12 & 4 & 0.48 & 4 & 0.48 \\
\hline Advanced of Technology & 0.06 & 3 & 0.18 & 2 & 0.12 \\
\hline Purchasing Power & 0.12 & 3 & 0.36 & 4 & 0.48 \\
\hline Loyality & 0.12 & 3 & 0.36 & 3 & 0.36 \\
\hline Market Prospects & 0.12 & 4 & 0.48 & 4 & 0.48 \\
\hline \multicolumn{6}{|l|}{ THREATS } \\
\hline Production Cost & 0.12 & 4 & 0.48 & 3 & 0.36 \\
\hline Competitors & 0.09 & 3 & 0.27 & 4 & 0.36 \\
\hline Imitation Product & 0.03 & 2 & 0.06 & 2 & 0.06 \\
\hline Raw Materials & 0.12 & 3 & 0.36 & 4 & 0.48 \\
\hline \multirow[t]{2}{*}{ Economic Condition } & 0.09 & 3 & 0.27 & 4 & 0.36 \\
\hline & 1.00 & & 3.33 & & 3.58 \\
\hline Total & & & 6.64 & & 7.10 \\
\hline
\end{tabular}

Source: Primary Data Analysis by Researchers (2020)

Calculation of the total attractiveness score of the internal and external factors of Istana Timber, the highest score was achieved for the market penetration strategy of 7.10 and the lowest was the Market Development strategy, which was 6.64. Based on the results of the 
calculation of the QSPM Matrix, the market penetration strategy is the best strategy that must be taken by Istana Timber in running its business. According to David and David (2016), a market penetration strategy is a strategy to find a larger market share for existing products or services through more aggressive marketing efforts. This strategy is widely used and combined with other strategies. Market penetration includes increasing the number of salespeople, increasing advertising expenses, offering extensive sales promotion of items, or increasing publication efforts, while market development strategies are strategies for introducing existing products or services to new geographic areas. This strategy requires the investment strength of a company to introduce products to a new area that has the potential for the company to increase product sales.

Istana Timber is currently classified as an SME. In SMEs, the capital sector is the biggest issue. Expanding product development in other areas takes a lot of money which is a big problem for SME businesses such as Istana Timber, coupled with the New Normal situation which creates limitations in the movement of people in economic activities. Meanwhile, to carry out a market penetration strategy by seeking new market share for existing products is considered more suitable and easier to do. The problem of increasing advertising costs or product introduction publications can be done at a low cost, by utilizing Internet technology to the fullest. Meanwhile, problems that may arise due to intensive promotions are the production capacity of Istana Timber which still has to be improved to anticipate the increase in sales by adding employees.

Based on the results of the research and the suitability of the theory, it can be concluded that the Market Penetration strategy is the most appropriate strategy to be used by Istana Timber in facing the current competition. The best long-term strategy that can be applied to Istana Timber is the Integration Strategy, namely by increasing the direct sales network to consumers, then increasing control over suppliers for product innovation development, and increasing competitiveness, including by taking over or acquiring smaller competitor shops. to enlarge the scale of Istana Timber's business.

\section{CONCLUSIONS}

To become a Hybrid Entrepreneur in the New Normal era, it must be based on expertise in the field to be pursued, as well as having the ability to seize opportunities and courage in making business decisions. Istana Timber is in Quadrant I of the Grand Strategies Matrix. The right strategy to use is the market development strategy and market penetration. Based on the results of the QSPM matrix calculation, the Market Penetration Strategy is the 
most appropriate strategy to be used by Istana Timber in facing competition in the New Normal era. The best long-term strategy is the Integration Strategy, namely by increasing the direct sales network to consumers, then increasing control over suppliers for product innovation development, and increasing competitiveness, including by taking over or acquiring smaller competitor shops to enlarge the business scale of Istana Timber.

The use of IFE, EFE, IE, SWOT, Grand Strategy, and QSPM analysis can be utilized by business people of all types of business to determine the most appropriate marketing strategy that can be applied to face competition in economic conditions in this New Normal era. Strengthening capabilities in the Human Resources sector in producing and utilizing technological advances in marketing can be a solution in the New Normal era in increasing company competitiveness in market development and penetration as a step to take full advantage of all existing opportunities. For further researchers, it is recommended to conduct research on effective and efficient market development and penetration techniques for types of small and medium-sized businesses in conditions of economic recession in the New Normal era due to the pandemic of Covid-19. 


\section{REFERENCES}

Agung, N.F.A., and Darma, G.S. (2019). Opportunities and Challenges of Instagram Algorithm in Improving Competitive Advantage, International Journal of Innovative Science and Research Technology, 4 (1): 743-747.

Arsriani, I.A.I., and Darma, G.S. (2013). Peran Media Sosial Online Dan Komunitas Terhadap Keputusan Nasabah Bank, Jurnal Manajemen dan Bisnis, 10 (2): 48-68.

Buheji, M., \& Ahmed, D. (2020). Planning for 'The New Normal' - Foresight and Management of the Possibilities of Socio- economic. Spillovers due to COVID-19 Pandemic, Business Management and Strategy, 11 (1): 160-179.

https://doi.org/10.5296/bms.v11i1.17044.

Darma, G.S., \& Noviana, I.P.T. (2020). Exploring Digital Marketing Strategies during the New Normal Era in Enhancing the Use of Digital Payment. Jurnal Mantik, 4 (3): 22572262. https://doi.org/10.35335/mantik.Vol4.2020.1084.pp2257-2262.

Darma, G.S., Wicaksono, K., Sanica, I.G., and Abiyasa, A.P. (2019). Faktor Kompensasi dan Strategi Gojek Dalam Meningkatkan Kepuasan Kerja Para Driver, JURNAL ILMIAH MANAJEMEN BISNIS DAN INOVASI UNIVERSITAS SAM RATULANGI, 6 (3): 232244.

Darma, G.S. (2018). A Message, Answering the Ages. Indonesia: Pustaka Larasan Press.

Darma, G.S. (2012). 100 Konsultasi Praktis Strategi Bisnis. Denpasar: Undiknas Press.

Darma, G.S. (2005). Konsultasi Praktis Marketing Strategy. Denpasar: Undiknas Press.

Darma, G.S. (2005). Managing Information to Greater Efficiency and Profit, Jurnal Ekonomi \& Bisnis, 17 (1): 1-10.

Darma, G.S. (2005). Teknologi Informasi, Kepuasan User, Kinerja User dan Kinerja Hotel di Bali, Jurnal Ekonomi \& Bisnis, 17 (2): 93-102.

Darma, G.S. (2004). Improving the Aligment of Business and Information Strategies, Jurnal Ekonomi \& Bisnis, 16 (1): 1-28.

Dharmayanti, P. D., \& Darma, G. S. (2020). The Use of Instagram in Coffee Shop, International Research Journal of Management, IT \& Social Sciences, 7 (4): 48-56. https://doi.org/10.21744/irjmis.v7n4.948

Dalimunthe, Br. H.H., Sutisna, A., Karnadi, Retnowati, E., Tijari, A. (2021). Social Enterpreneurship Empowerment in The Indonesian Archipelagic Communities, Indonesian Journal of Business and Entepreneurship, 7 (2): $103-110$. https://doi.org/10.17358/IJBE.7.2.103.

David, F.R. (2012). Concept of Strategic Management. Jakarta: Salemba Empat. 
David, F.R., \& David, F. R. (2016). Strategic Management: A Competitive Advantage Approach Concept $15^{\text {th }}$ Edition. Jakarta: Salemba Empat.

Dewi, M.V.K., and Darma, G.S. (2019). The Role of Marketing \& Competitive Intelligence In Industrial Revolution 4.0, Jurnal Manajemen \& Bisnis, 16 (1): 1-12.

Dewi, N.M.A.T., and Darma, G.S. (2016). Efektivitas Leadership, Growth Performance dan Regulasi Otoritas Jasa Keuangan, Jurnal Manajemen \& Bisnis, 13 (1): 1-13.

Folta., Timothy, B., Delmar, F., Wennberg, K. (2010). Hybrid Entrepreneurship, Management Science Journal, 56 (2): 253-269. https://doi.org/10.1287/mnsc.1090.1094.

Ferdiana, A.M.K., and Darma, G.S. (2019). Understanding Fintech Through Go-Pay, International Journal of Innovative Science and Research Technology, 4 (2): 257-260.

Ferreira, C.C., Ferguson, S.L., and Pitt, L.F. (2019). Entrepreneurial marketing and hybrid entrepreneurship: the case of JM Reid Bamboo Rods, Journal of Marketing Management, 35 (9-10): 867- 885. https://doi.org/10.1080/0267257X.2019.1637921. Handayani, L.P.D.S., \& Darma, G. S. (2021). Pengaruh Kebijakan Pemeriksaan, Kebijakan Akses Informasi Keuangan dan Forensik Digital terhadap Kualitas Pemeriksaan Pajak, Syntax Literate; Jurnal Ilmiah Indonesia, 6 (3), 1260-1272.

http://dx.doi.org/10.36418/syntax-literate.v6i3.1142

Hendro., dan Chandra WW. (2006). Be a Smart and Good Enterpreneur. Jakarta: Erlangga.

Handika, M.R., and Darma, G.S. (2018). Strategi Pemasaran Bisnis Kuliner Menggunakan Influencer Melalui Media Sosial, Jurnal Manajemen \& Bisnis, 15 (2): 188-199.

Hendhana, S., and Darma, G.S. (2017). Service Quality Rumah Sakit dan Efeknya terhadap Patient Satisfaction, Perceived Value, Trust, dan Behavioral Intention, Jurnal Manajemen \& Bisnis, 14 (1): 37-55.

Karniawati, N.P.A., Darma, G. S., Mahyuni, L.P., \& Sanica, I.G. (2021). COMMUNITY PERCEPTION OF USING QR CODE PAYMENT IN ERA NEW NORMAL. PalArch's Journal of Archaeology of Egypt/Egyptology, 18 (1): 3986-3999.

Kusnadi, D.S., and Darma, G.S. (2018). Menakar Implementasi Green Marketing Pada Usaha Kecil Menengah, Jurnal Manajemen \& Bisnis, 15 (1): 1-18.

Kusuma, P. O., \& Darma, G. S. (2020). Mobile Payment Transaction on MSMEs, International Research Journal of Management, IT \& Social Sciences, 7 (3): 104-109. https://doi.org/10.21744/irjmis.v7n3.926.

Krismajayanti, N.P.A., \& Darma, G. S. (2021). Eksplorasi Loyalitas Millennial Terhadap Brand Apple. Prestige or Needs?, Jurnal Manajemen dan Bisnis (Performa), 18 (3): $32-44$. 
Ledriyono, F. (2021). Public's Perception on Social Media towards New Normal during Covid19 Pandemic in Indonesia : Content Analysis on Religious Social Media Accounts, IOP Conference Series : Earth and Environmental Science, 717 (2021) 012039. https://doi.org/10.1088/1755-1315/717/1/012039

Marshall, D.R., Meek, W.R., Swab, R.G., Markin, E. (2020). Access to Resources and Entpereneurial Well-being : A Self-efficacy Approach, Journal of Business Research, 120 (2020): 203 - 212. https://doi.org/10.1016/j.jbusres.2020.08.015.

Mahmud., and Ariati A., (2011). Analysis of The Effect of Entepreneurial Orientation, Management Ability, and Business Strategy in Improving Company Performance (Study of SMEs in Barito Semarang Business Area), Journal of Economics and Business, Dian Nuswantoro University Semarang.

Maharani, I.G.A.P.D., and Darma, G.S. (2018). Consumer Purchasing Behavior Analysis on Impulse Buying, Jurnal Manajemen \& Bisnis, 15 (3): 16-37.

Murti, K.G.K., \& Darma, G. S. (2021). Jalan Terjal Online Travel Platform Hadapi Pandemi. Syntax Literate; Jurnal Ilmiah Indonesia, $6 \quad$ (5): 2280-2296. http://dx.doi.org/10.36418/syntax-literate.v6i5.2703

Permanasari, I.A.S., and Darma, G.S. (2013). Pengaruh Penggunaan Internet Banking Terhadap Rasa Aman, Rasa Percaya Dan Loyalitas Nasabah Dalam Meningkatkan Saldo Bank, Jurnal Manajemen dan Bisnis, 10 (1): 186-204.

Pollack, J.M, Carr, J.C., Michaelis, T.L., Marshall, D.R. (2019). Hybrid Entepreneurs' Selfefficacy and Persisctence Change : A Longitudinal Exploration, Journal of Business Venturing Insights, 12 (2020). https://doi.org/10.1016/j.jbvi.2019.e00143

Poliyando, P., and Kartiwi. (2021). New Model of Local Government Administrative Service in a New Normal Pattern of Behavior Era in Indonesia, International Journal of Criminology and Sociology, 10: 766 - 777.

Priskila, S., \& Darma, G.S. (2020). Employee Perception of Brand Value in the Jewelry Industry, Journal of Economics, Business, \& Accountancy Ventura, 23 (2). http://dx.doi.org/10.14414/jebav.v23i2.2281.

Reema, B., Soundara, R., and Seema, S. (2019) Evaluation of Personal Innovativeness and Perceived Expertise on Digital Marketing Adoption By Women Entrepreneurs of Micro and Small Enterprises, International Journal of Research and Analytical, 6 (1): 338-351.

Rivaldo, I. M. G., Lestari, N.P.N.E., \& Darma, G.S., \& Gorda, A.A.N.E.S. (2021). Integrating The Credit Lending Strategies of Multi-Purpose Cooperatives (a Case Study at KSU 
Dauh Ayu in Denpasar), Jurnal Mantik, 4 (4): 2318-2324. https://doi.org/10.35335/mantik.Vol4.2021.1138.pp2318-2324

Shavitri, L.P.D., \& Darma, G.S. (2020). Pengaruh Implementasi Kebijakan Pemeriksaan dan Forensik Digital terhadap Kualitas Pemeriksaan dan Keberhasilan Penerimaan Pajak, $\begin{array}{lllllll}\text { E-Jurnal } & \text { Akuntansi, } & 30 & (10): & 2682 & - & 2697 .\end{array}$ https://doi.org/10.24843/EJA.2020.v30.i10.p19

Sudiwedani, A., \& Darma, G.S. (2020). Analysis of the effect of knowledge, attitude, and skill related to the preparation of doctors in facing industrial revolution 4.0, Bali Medical Journal, 9 (2): 524-530. https://dx.doi.org/10.15562/bmj.v9i2.1895.

Swari, D.A.K.B.A., and Darma, G.S. (2019). Kepercayaan Lintas Generasi Dalam Penggunaan Social Media dan Electronic Word of Mouth, Jurnal Manajemen Bisnis, 16 (4): 145161.

Saturwa, H.N., Suharno, Ahmad, A.A. (2021). The Impact of Covid-19 Pandemic on MSMEs, Jurnal Ekonomi dan Bisnis, 24 (1): 65 - 82.

Saefulloh, D.A., and Darma, G.S. (2014). Strategi Marketing Wisata Wedding Sebagai Destinasi Alternatif, Jurnal Manajemen \& Bisnis, 11 (1): 17-34.

Sparrow, R., Dartanto, T., Hartwig, R. (2020). Indonesia Under the New Normal : Challenges and the Way Ahead, Bulletin of Indonesian Economic Studies, 56 (3): 269 - 299. https://doi.org/10.1080/00074918.2020.1854079.

Tay, L.C., Tan, F.Y., Yahya, K.K. (2019). The Power of Ability - Motivation - Opportunity Enhancing Human Resource Management Practices on Organizational Ecthical Climate, International Journal of Business and Society, 8 (3): 547 - 562.

Umami, Z., \& Darma, G. S. (2021). DIGITAL MARKETING: ENGAGING CONSUMERS WITH SMART DIGITAL MARKETING CONTENT, Jurnal Manajemen dan Kewirausahaan, 23 (2): 94-103. https://doi.org/10.9744/jmk.23.2.94-103.

Wardana, M.A.K., Cahyadi, E.R., Slamet, A.S. (2021). A Comparison of Perceptions and Adapted Behaviors Between Employees and Entepreneurs Against Pandemic Covid19 Pandemic, Indonesian Journal of Business and Entepreneurship, 7 (2): 129 - 138. https://doi.org/10.17358/IJBE. 7.2.139.

Wardana, I.M.A., \& Darma, G.S. (2020). Garment Industry Competitive Advantage Strategy During Covid-19 Pandemic. PalArch's Journal of Archaeology of Egypt / Egyptology, https://www.archives.palarch.nl/index.php/jae/article/view/2732. 
Wandari, N.K.M.A., \& Darma, G. S. (2021). Pengelolaan Karakter Green-Behavior Pada Generasi Milenial Dalam Meningkatkan Minat Penggunaan Green-Product. Jurnal Nusantara Aplikasi Manajemen Bisnis, 6 (1): 49-61. https://doi.org/10.29407/nusamba.v6i1.14778.

Wahyuni, N.W.S., and Darma, G.S. (2019). Mobile Advertising, Product Social Value dan Purchase Intention pada Instagram, Jurnal Manajemen Bisnis, 16 (4): 87-101.

Widya Hati, S. (2019). Antecedents of Entrepreneurial Intentions (Entrepreneurial Intentions) in Airlangga University Students (Studies on WEBS Member Students, Faculty of Economics and Business), Jurnal Ilmiah Manajemen dan Bisnis, 4 (2): 97 - 114.

Wijaya, Y.A. (2021). Risk Management Mitigation in The New Normal Era, Budapest International Research and Critics Institute - Journal (BIRCI - Journal), 4 (1): 10881097. https://doi.org/10.33258/birci.v4i1.1716.

Wulandari, N.L.P.T., \& Darma, G.S. (2020). Textile Industry Issue in Pandemic of Covid-19. PalArch's Journal of Archaeology of Egypt / Egyptology, 17 (7): 8064-8074. Retrieved from https://archives.palarch.nl/index.php/jae/article/view/3526.

Wulandari, L.P.A., \& Darma, G.S. (2020). Advertising Effectiveness in Purchasing Decision on Instagram. Journal of Business on Hospitality and Tourism, 6 (2): 381-389. http://dx.doi.org/10.22334/jbhost.v6i2.220

Xi, G., Block, J.H., Lasch, F., Robert, F., Thurik, R. (2017). Mode of Entry into Hybrid Entrepreneurship: New Venture Start-Up versus Business Takeover. Discussion Paper 11104 : IZA Institute of Labor Economics.

Yong, I.D., \& Darma, G.S. (2020). Indikator Penentu Naik Turunnya Harga Saham pada Perusahaan High Deviden 20 Periode Tahun 2014-2019, Syntax Literate ; Jurnal Ilmiah Indonesia, 5 (12): 1591-1610. doi:10.36418/syntax-literate.v5i12.1907 